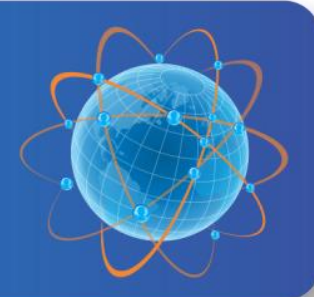

\title{
Perubahan Infrastruktur Sosial Sebagai Implikasi Perubahan Sistem Pertanian (Kasus Pada Masyarakat Petani Kelapa Sawit)
}

Authors : Desi Yunita

Published by : Departemen of Sociology, Faculty of Social and Political Science, Universitas Padjadjaran

Accepted : Februari 2017; Approved : March 2017

Sosiogobal: Jumal Pemikiran dan Penelitian Sosiologi is the Department of Sociology, Faculty of Social and Political Science, Universitas Padjadjaran flagship journal. The Sosioglobal journal founded in 2016 with the mission to publish original works of interest to the discipline of sociology in general, sociological thinking, new theoretical developments, results of research that enhance understanding of fundamental social processes, and methodological innovations. We are welcome a research article, working paper, theoretical/conceptual and methodological review to submit to our journal. In addition, we are accept relevant book review that currently publish and enrich sociological perspectives. Please submit article to http://jurnal.unpad.ac.id/sosioglobal

To cite this article :

Yunita, Desi.2017.Perubahan Infrastruktur Sosial Sebagai Implikasi Perubahan Sistem Pertanian (Kasus Pada Masyarakat Petani Kelapa Sawit).Sosioglobal : Jurnal Pemikiran dan Penelitian Sosiologi $1(2): 115-131$. 


\title{
PERUBAHAN INFRASTRUKTUR SOSIAL SEBAGAI IMPLIKASI PERUBAHAN SISTEM PERTANIAN \\ (Kasus Pada Masyarakat Petani Kelapa Sawit)
}

\author{
Desi Yunita ${ }^{1}$ \\ ${ }^{1}$. Prodi Sosiologi, Fakultas Ilmu Sosial dan Ilmu Politik, Universitas Padjadjaran \\ desi.yunita@unpad.ac.id
}

\begin{abstract}
ABSTRAK
Salah satu faktor yang mempengaruhi terjadinya perubahan sosial dalam masyarakat petani adalah perubahan system pertanian. Masyarakat yang awalnya merupakan petani subsisten, saat ini telah berubah menjadi petani yang berorientasi industry dengan menjadi petani monokultur kelapa sawit. Penelitian dilakukan untuk mengetahui perubahan infrastruktur social yang terjadi sebagai konsekuensi dari perubahan sistem pertanian tersebut. Metode kualitatif dengan teknik pengumpulan data melalui wawancara mendalam, observasi, serta studi dokumentasi dipilih sebagai teknik dalam pengumpulan data. Analisis hasil penelitian menggunakan analisis materialisme budaya oleh Marvin Harris. Hasil penelitian menunjukkan bahwa adanya perubahan system pertanian telah mendorong terjadinya perubahan sosial mendasar dalam masyarakat. Perubahan mendasar ini sering disebut sebagai perubahan infrastruktur. Adapun perubahan-perubahan yang termasuk dalam perubahan infrastruktur tersebut adalah pada mode produksi seperti perubahan pola tanam, pola produksi dan teknologi, aktivitas kerja, dan fungsi lahan. Dan perubahan mode reproduksi berupa perubahan komposisi penduduk dengan adanya penambahan jumlah penduduk melalui transmigrasi.
\end{abstract}

Kata kunci: perubahan infrastruktur, mode produksi, mode reproduksi

\begin{abstract}
One of the factors that affect social change in farming communities is the change in the agricultural system. People who initially are subsistence farmers, has now turned into a farmer-oriented industry to become monoculture palm oil plantations farmers. The study was conducted to determine the social infrastructure changes that occur as a consequence of changes in the agricultural system. Qualitative methods with data collection through interviews, observation, and documentation study selected as a technique in data collection. Analysis of the results using the analysis of cultural materialism by Marvin Harris. The results showed that the change in the agricultural system has led to the fundamental social changes in society. Fundamental change is often referred to as the infrastructure changes. The changes included in the infrastructure changes are in the mode of production such as changes in cropping patterns, patterns of production and technology, work activities, and land use. And a reproduction mode changes include changes in population composition with the addition of a population through transmigration.
\end{abstract}

Keywords : infrastructure changes, mode of production, mode of reproduction 


\section{PENDAHULUAN}

Tahun 1995 adalah tahun bersejarah bagi perkembangan perkebunan kelapa sawit di Indonesia, karena pada tahun itu perkebunan kelapa sawit menjadi booming hampir diseluruh wilayah Indonesia. Berkembangnya perkebunan kelapa sawit tersebut telah menjadi peluang bagi banyak masyarakat indonesia untuk memperbaiki tingkat kesejahteraannya. Penelitian terdahulu menyebutkan beberapa perubahan yang terjadi seiring dengan berkembangnya perkebunan kelapa sawit tersebut, diantaranya; perubahan tingkat kehidupan masyarakat sebagai akibat terjadinya perubahan sistem penguasaan dan kepemilikan lahan, seperti diungkapkan oleh Syahaza, 2005; Rusmawardi, 2007; Rosariyanto, et.al, 2008; Herman et.al, 2009; dan Elfitra, 2010. Perubahan sistem mata pencaharian seperti diungkapkan oleh Syahaza (2005). Perubahan sistem pertanian akan menurunkan kemampuan masyarakat untk mengembangkan mata pencaharian berkelanjutan melalui cara diversifikasi, seperti diungkapkan oleh Marti (2008:70).

Selain telah memberikan perubahan yang bermakna positif karena telah mendorong adanya peningkatan kehidupan dan kesejahteraan masyarakat, perubahan sistem pertanian menjadi monokultur ini juga memiliki dampak negatif yang tidak sedikit. Beberapa penelitian terdahulu seperti yang dilakukan oleh Effendy, 1996; Manurung, 2001; Colchester, 2006; Murtilaksono, et.al, 2007; Marti, 2008; Widiono, 2008; Wigena, et.al, 2008; Yel dan PaNeco, 2008; Sawit Watch, 2009; Susila dan Drajad, 2009; Elfitra, 2010 menyebutkan bahwa pembukaan lahan untuk dijadikan perkebunan kelapa sawit yang telah dilakukan selama ini juga menimbulkan berbagai macam dampak terhadap kehidupan ekonomi, sosial, dan budaya bagi petani, dan juga menimbulkan dampak terhadap lingkungan.

Yel dan PanEco Foundation (2008:2) menggambarkan bahwa perusahaan kelapa sawit dengan keberadaannya telah mengganggu keseimbangan ekosistem hutan, akibatnya aktivitas perkebunan kelapa sawit dapat menjadi ancaman bagi ekologis tempatan, yang sangat besar mendorong terjadinya degradasi lingkungan. Sedangkan Achmad (2007) menjelaskan bahwa perluasan perkebunan kelapa sawit memiliki beberapa dampak, yaitu; (1) Perubahan tata ruang, (2) Homogenitas dan konversi hutan yang berlebihan, (3) Hilangnya keanekaragaman hayati, dan (4) Akan memicu kerentanan kondisi alam berupa menurunnya kualitas lahan disertai erosi, hama dan penyakit. Belum lagi pertumbuhan kelapa sawit mesti dirangsang oleh berbagai macam zat sejenis pestisida dan bahan kimia lainnya. ${ }^{1}$ Kemudian banyaknya unsur

\footnotetext{
${ }^{1}$ Achmad, Saiful. 2007. Tentang Dampak Ekologi Dan Lingkungan Akibat Perkebunan Sawit Skala Besar. http://adekrawie.wordpress.com.
} 
hara dan air tanaman dari perkebunan monokultur seperti kelapa sawit, dalam satu hari satu batang pohon kelapa sawit bisa menyerap 12 liter. $^{2}$

Selanjutnya, selain mendorong terjadinya perubahan dan juga adanya potensi kerentanan yang akan terjadi sebagai akibat dari perkembangan perkebunan kelapa sawit, disisi yang lain diterapkannya kebijakan pembangunan perkebunan monokultur kelapa sawit, dengan sistem perkebunan inti rakyat (PIR) sangat bepotensi memicu terjadinya perubahan yang sangat sistematis di dalam masyarakat petani. Dengan pola top down yang cenderung memaksa telah menempatkan masyarakat pada pilihan yang sulit. Di sisi lain harapan-harapan akan kesejahteraan yang ditawarkan telah menggiring masyarakat petani semakin tidak memiliki pilihan, seperti keuntungan yang lebih besar dan meningkatnya standar hidup yang lebih layak.

Melihat fenomena perkebunan kelapa sawit yang berkembang secara massif dan sistematis tersebut, sangat menarik kiranya untuk juga mengetahui perubahan sosial apa saja yang telah terjadi di masyarakat seiring dengan berkembangnya perkebunan kelapa sawit tersebut. Perubahan sosial yang terjadi di masyarakat ini secara khusus akan dibedah menggunakan pisau analisis materialisme kultural Marvin Harris yang mengklasifikasikan perubahan kedalam 3 bentuk yaitu perubahan infrastruktur, struktur, dan suprastruktur.

Penelitian ini secara khusus akan difokuskan pada aspek sosiologis dari perkembangan perkebunan kelapa sawit, peneliti hanya akan berfokus pada satu klasifikasi perubahan sosial saja yaitu perubahan infrastruktur yang terjadi dalam masyarakat petani sawit monokultur dengan sistem perkebunan inti rakyat (PIR). Adapun dimensi perubahan yang akan dilihat dalam perubahan infrastruktur tersebut adalah perubahan pada mode produksi dan mode reproduksi.

\section{METODE PENELITIAN}

Metode kualitatif dengan teknik pengumpulan data melalui wawancara mendalam, observasi, serta studi dokumentasi dipilih sebagai teknik dalam pengumpulan data. Pemilihan metode dengan seperangkat teknik pengumpulan data ini dinilai tepat dalam mengumpulkan beragam informasi yang diperlukan untuk mengetahui proses perubahan sosial apa saja yang termasuk dalam kategori perubahan infrastruktur tersebut.

Sumber informasi adalah semua anggota masyarakat yang merupakan subjek peneliti, salah satunya adalah petani kelapa sawit sawit di Kabupaten Bengkulu Utara. Sedangkan data yang ingin digali diantaranya kondisi masyarakat sebelum dan sesudah diterapkannya pola pertanian

2Sirait, Roida Elfrika. 2010. Selamatkan Lingkungan Jika Kau Ingin Selamat. http://www.mediaindonesia.com.

117 | STSIOGLOBAL : Jurnal Pemikiran dan Penelitian Sosiologi, Vol. I, No. 2, Juni 2017 
monokultur, perubahan infrastruktur masyarakat akibat diterapkannya perkebunan monokultur. Serta juga informasi dari perusahaan yang menjadi mitra petani. Informan penelitian ini ditentukan dengan menggunakan teknik bola salju. Pendekatan penelitian ini dipilih untuk memudahkan penggalian informasi tanpa harus dibatasi individu-individu yang dapat menjadi informan. Dengan pendekatan seperti ini maka data yang akan diperoleh menjadi sangat kaya dan beragam.

Dalam menganalisa data, proses analisis data dilakukan secara bertahap disesuaikan dengan data yang sudah diperoleh dan dalam mengolah data tersebut peneliti tidak menunggu ketika data terkumpul semua, melainkan data akan dioleh secara bertahap untuk mengetahui sejauh mana tingkat pemenuhan dan ketersediaan data penelitan yang telah didapat, dan jika dirasa kurang maka proses penelitian lapangan masih akan terus dilakukan. Proses analisa data dalam penelitian ini meliputi; pengujian, pemilihan, kategorisasi, evaluasi, membandingkan, melakukan sintesa, dan merenungi kembali data yang peneliti peroleh untuk membangun inferensi-inferensi dan kemudian menarik kesimpulan sehingga tercapainya pemahaman secara holistik.

Sedangkan untuk mengukur akurasi dan keabsahan data dilakukan dengan cara membandingkan situasi masyarakat petani Suku Pekal yang mengikuti pola tanam monokultur dan yang masih mengikuti pola tanam polikultur. Membandingkan data hasil pengamatan dengan hasil wawancara dari informan penelitian, memandingkan apa yang dikatakan orang di depan umum dan apa yang dikatakan informan secara pribadi. Membandingkan keadaan dan perspektif informan dengan masyarakat lain, pemerintah dan pihak perusahaan. Memandingkan hasil wawancara dengan isi dokumen-dokumen terkait yang diperoleh baik dari desa maupun perusahaan sawit.

\section{KERANGKA TEORI/KONSEP}

Perubahan sosial sejatinya merupakan perubahan pada struktur sosial dalam suatu masyarakat. Dalam kerangka berfikir Marx perubahan sosial itu merupakan produk dari sebuah proses produksi (Materialisme) yang terjadi akibat adnaya akumulasi modal (capital) atau dengan kata lain dapat dikatakan bahwa perubahan sosial adalah perubahan yang terjadi karena perkembangan teknologi dan terjadinya perubahan hubungan antar kelas-kelas sosial. Sehingga jika dikembalikan pada konteks masyarakat petani, masuknya perkebunan dengan perangkat sistem yang mengikutinya secara pasti telah mendorong terjadinya perubahan sosial dalam masyarakat petani. 
Secara sederhana Kingsley Davis (dalam Setiadi, 2011:10) mengartikan perubahan sosial sebagai perubahan-perubahan yang terjadi dalam struktur dan fungsi masyarakat. Akan tetapi perubahan sosial tidak hanya berupa kemajuan tetapi dapat pula berupa kemunduran sebagaimana definisi perubahan sosial yang dikemukakan oleh Hans Grath dan C. Wright Mills (dalam Setiadi, 2011:10) bahwa perubahan sosial adalah apapun yang terjadi (kemunculan, perkembangan dan kemunduran) dalam kurun waktu tertentu terhadap peran, lembaga atau tatanan yang meliputi struktur sosial.

Sztompka (2007:3) memaparkan perubahan sosial itu dapat dibedakan menjadi beberapa jenis. Hal ini tergantung dengan sudut pengamatannya, apakah dari sudut aspek, fragmen atau dimensi sistem sosialnya. Hal ini dikarenakan sistem sosial masyarakat itu tidaklah sederhana, tidak hanya berdimensi tunggal, tetapi muncul sebagai kombinasi atau gabungan hasil keadaan berbagai komponen berikut ini :

1. Unsur-unsur pokok (Misalnya; jumlah dan jenis individu, serta tindakan mereka)

2. Hubungan antar unsur (Misalnya; ikatan sosial, loyalitas, ketergantungan, hubungan antar individu, integerasi)

3. Berfungsinya unsur-unsur di dalam sistem (Misalnya; peran pekerjaan yang dimainkan oleh individu atau diperlakukannya tindakkan tertentu untuk melestarikan ketertiban sosial)

4. Pemeliharaan batas (Misalnya; kriteria untuk menentukan siapa saja yang termasuk anggota sistem, syarat penerimaan individu dalam kelompok, prinsip rekrutmen dalam organisasi dan sebagainya)

5. Subsistem (Misalnya; jumlah dan jenis seksi, segmen, atau divisi khusus yang dapat dibedakan)

6. Lingkungan (Misalnya; keadaan alam, atau lokasi geopolitik)

Uraian yang dikemukakan Sztompka tersebut secara gamblang semakin menjelaskan bentuk perubahan sosial, namun perubahan sosial yang digambarkan tersebut belum dapat menggambarkan perubahan sosial secara spesifik seperti perubahan sosial yang tejadi pada masyarakat petani.

Justru apa yang dikemukakan oleh Marx Marx (dalam Suseno, 2010:112) yang menyebutkan bahwa pelaku-pelaku utama perubahan sosial bukanlah individu-individu tertentu, melainkan kelas-kelas sosial, karena itu kita hanya dapat memahami sejarah dan perkembangan yang terjadi apabila kita memperhatikan kelas-kelas sosial dalam masyarakat. Marx mengemukakan bahwa bahwa dalam setiap masyarakat terdapat kelas-kelas yang berkuasa dan kelas-kelas yang 
dikuasai, kelas-kelas atas dan kelas-kelas bawah. Menurut Marx masyarakat kapitalis terdiri atas tiga kelas yakni, kaum buruh (mereka hidup dari upah), kaum pemilik modal (yang hidup dari laba) dan para tuan tanah, pada perkembangan selanjutnya tersisa dua kelas, kaum buruh dan pemilik modal. Fenomena yang digambarkan oleh Marx inilah yang justru terlihat pada masyarakat perkebunan kelapa sawit dengan sistem PIR.

Berdasarkan hasil analisis yang dikembangkan oleh Marx tersebut Marvin Harris memperkenalkan sebuah konsepsi analisis untuk dapat menganalisa perubahan sosial yang terjadi pada masyarakat melalui pendekatan materialisme budaya, dimana dalam pendekatan ini Marvin Harris sangat dipengaruhi oleh gagasan Marxis tentang basis (Base) dan Suprastruktur. Marvin Harris menyebut basis sebagai infrastruktur. Marvin Harris memodifikasi skema marxis dengan memasukkan unsur reproduksi manusia ke dalam basis (infrastruktur) bersamasama dengan mode ekonomi dari produksi. Selain itu, Harris juga mengusulkan suatu kategori "antara" (intermediate category), yakni struktur, di antara basis dan suprastruktur. Suatu kategori yang tidak terdapat dalam skema marxis (Saifuddin, 2010:236).

Maka dengan menggunakan pendekatan Marvin Harris dalam melihat perubahan sosial, maka dapat diamati bagaimana perubahan infrastruktur dalam masyarakat petani perkebunan kelapa sawit mendorong terjadinya perubahan struktur dalam masyarakat.

\section{PEMBAHASAN}

Hasil penelitian menunjukkan bahwa masuknya perkebunan kelapa sawit sangat berperan dalam mendorong terjadinya perubahan dalam masyarakat. Perubahan infrastruktur dalam paradigma Cultural Materialisme Marvin Harris terdiri dari perubahan mode produksi dan perubahan mode reproduksi yang merupakan basis perubahan dalam suatu masyarakat. Jika infrastruktur berubah maka struktur sosial berubah dan akan mendorong terjadi perubahan suprastrukturnya pula, demikian sebaliknya jika suprastrukturnya berubah, maka akan merubah struktur sosial dan infrastrukturnya. Untuk lebih jelasnya dapat dilihat pada tabel berikut ini:

Tabel 1. Perubahan Infrastruktur Pada Masyarakat Petani Kelapa Sawit Pola PIR

\begin{tabular}{ccl}
\hline \hline No & Jenis Perubahan & \multicolumn{1}{c}{ Bentuk Perubahan } \\
\hline 1 & Mode Produksi & Pola Tanam \\
\cline { 3 - 3 } & & Pola Produksi dan teknologi \\
\cline { 3 - 3 } & & Bentuk Aktivitas Kerja \\
\cline { 3 - 3 } & & Fungsi Lahan \\
\hline 2 & Mode Reproduksi & Komposisi Jumlah Penduduk \\
\hline
\end{tabular}




\section{Perubahan Mode Produksi}

Perubahan infrastruktur masyarakat petani dalam hal ini perubahan pada mode produksi ditandai dengan masuknya perusahan kelapa sawit dan program perkebunan dengan kemitraan plasma, sementara perubahan mode reproduksi dalam masyarakat dengan masuknya transmigrasi dan perkembangan komposisi penduduk dengan pengaruh program Keluarga Berencana sebagai upaya membatasi jumlah penduduk. Perubahan infrastruktur ini mendorong perubahan pada : 1) pola tanam; 2) status dan kepemilikan lahan; 3) perubahan pada unit dan pola produksi dan teknologi.

Perubahan mode produksi dari sistem pertanian polikultur menjadi sistem pertanian monokultur pada masyarakat petani tidak lepas dari kebijakan pembangunan berupa Instruksi Presiden (Inpres) Nomor 1 Tanggal 3 Maret Tahun 1986 tentang Pengembangan Perkebunan dengan Pola Perusahaan Inti Rakyat yang dikaitkan Dengan Program Transmigrasi. Kebijakan ini memberikan legitimasi kepada perusahaan-perusahaan perkebunan swasta untuk membuka lahan-lahan perkebunan di daerah-daerah yang dianggap cocok untuk pengembangan kelapa sawit, terutama wilayah yang masih memiliki lahan-lahan hutan yang masih luas.

Masuknya perusahaan kelapa sawit yang mendorong perubahan mode produksi masyarakat petani didasarkan pada kebijakan pembangunan pemerintah yang menunjukan bahwa struktur sosial (lembaga pemerintah) dengan kebijakan pembangunan pertaniannya mempengaruhi perubahan infrastruktur masyarakat (mode produksi masyarakat). Walaupun dalam Cultural Materialisme dikatakan bahwa perubahan infrastruktur sangat dominan dalam mendorong perubahan sosial dalam masyarakat, akan tetapi antara infrastruktur, struktur dan suprastruktur dapat saling mempengaruhi. Marvin Harris menjelaskan bahwa secara faktual hubungan antar unsur-unsur struktur ini kompleks, karena infrastruktur bukanlah faktor penggerak utama tunggal melainkan keterjalinan, kaitan yang kompleks. Hasil penelitian menunjukkan bahwa perubahan-perubahan mode produksi adalah sebagai berikut:

Tabel 2. Perubahan-Perubahan Pada Mode produksi

\begin{tabular}{l}
\hline Perubahan Mode Produksi \\
\hline 1. Perubahan pada pola tanam \\
\hline 2. Perubahan pada pola produksi dan teknologi \\
\hline 3. Perubahan pada Aktivitas kerja \\
\hline 4. Perubahan Fungsi Lahan (Ekosistem)
\end{tabular}

Dalam penelitian ini terungkap bahwa pembukaan lahan perkebunan dan program plasma yang dipraktekkan, menyebabkan pemerintah kehilangan hak kontrol terhadap kebijakankebijakan perusahaan dalam proses produksinya dan kebijakan-kebijakan perusahaan 
berhubungan dengan masyarakat, pemerintah hanya sekedar memberikan izin kepada perusahaan akan tetapi tidak bisa terlibat dalam masalah perusahaan dan petani. Pemerintah mengikuti dan mengakomodasi kebijakan perusahaan, hal ini seperti terlihat salah satunya pada saat PT. Agricinal pertama kali masuk ke wilayah bengkulu utara pada tahun 1982. Dimana setelah proses awal ini pemerintah daerah mengeluarkan aturan untuk memberikan tanah desa/tanah adat desa kepada perusahaan untuk dijadikan sebagai perkebunan percontohan dan tanah desa/tanah adat desa tersebut menjadi milik perusahaan.

Pada kasus perubahan mode produksi, perusahaan lebih diuntungkan dari petani. Hal tersebut terlihat dari berubahnya status lahan yang tadinya merupakan milik komunal masyarakat berubah menjadi milik perusahaan. Masyarakat kehilangan hak kontrol komunal terhadap tanah adat desa. Hak atas tanah tersebut menjadi milik perusahaan dan menjadi hak perusahaan memperlakukan lahan tersebut, termasuk tindakan yang dapat menyebabkan kerusakan pada lingkungan (tanah dan air). Padahal tanah tersebut menjadi bagian ekosistem dalam kehidupan masyarakat.

Perusahaan dalam hal ini lebih mengedepankan faktor-faktor keuntungan yang akan didapat dari usaha perkebunan kelapa sawit tersebut dengan menjadikan lahan yang dikuasakan kepadanya dan juga lahan milik petani sebagai komoditi yang dikelola agar perusahaan mendapat keuntungan. Perusahaan menjadi tidak peduli dengan aspek-aspek lain dalam proses pembukaan dan pengelolaan perkebunan kelapa sawit, seperti dampak terhadap lingkungan atau dampak terhadap kehidupan masyarakat yang terlibat langsung atau tidak langsung dalam program pembukaan perkebunan kelapa sawit.

Upaya perusahaan untuk mendapat keuntungan yang lebih besar, mendorong perusahaan melakukan perluasaan kepemilikan lahan untuk dijadikan sebagai perkebunan dengan membeli lahan-lahan milik petani. Artinya masuknya perusahaan dengan program perkebunan tidak hanya menyebabkan masyarakat kehilangan lahan desa/lahan adat akan tetapi masyarakat sedikit demi sedikit kehilangan kepemilikan lahan karena dijual kepada perusahaan.

Selain petani kehilangan kepemilikan lahan, pembukaan perkebunan kelapa sawit pada akhirnya juga berdampak kepada kehidupan sosial masyarakat dan berdampak pada ekosistem lingkungan. Sebagaimana pula dijelaskan oleh Sawit watch (2008:16-17) bahwa di mana kedatangan perkebunan kelapa sawit telah merubah tatanan kehidupan masyarakat lokal dan menghancurkan budaya serta nilai-nilai dan kearifan lokal. Tradisi dan ritual yang telah menjadi praktek pertanian dalam hutan juga telah hilang ditandai dengan semakin instannya masyarakat dalam berpikir, lebih berorientasi keuntungan dibandingkan keserasian dengan alam. 
Paradigma Cultural Materialisme Marvin Harris menyebutkan keterkaitan erat perubahan mode produksi dengan perubahan struktur sosial baik pada ekonomi domestik keluarga petani maupun ekonomi politik masyarakat. Marvin Harris mengungkapkan bahwa perubahan sosial diakibatkan oleh perubahan mode produksi. Sementara mode produksi adalah proses produksi, teknologi dan ekosistem (lahan). Maka mengikuti analisis Marx dan Marvin Harris perubahan mode produksi masyarakat petani akan mendorong perubahan struktur sosial pada masyarakat. Siapa yang menguasai lahan yang banyak maka ia akan berada dalam posisi tertinggi dalam struktur sosial.

Hal ini menempatkan posisi perusahaan pada posisi tinggi dalam struktur sosial masyarakat. Perusahaan menjadi pengontrol kebijakan pertanian karena kepemilikan sumber produksi (lahan perkebunan dan modal). Sementara petani menjadi pekerja dalam proses produksi dikontrol oleh perusahaan.

Berkaitan dengan proses perubahan mode produksi, petani tentunya tidak akan begitu saja menerima perubahan mode produksi yang bari ini. Sebab mode produksi berkaitan erat dengan kebutuhan hidup petani. Mode produksi akan berkaitan erat dengan pendapatan dan pemenuhan kebutuhan petani. Sehingga tidak mudah bagi petani mengubah mode produksinya kecuali petani beranggapan bahwa perubahan tersebut akan mengantarkan petani pada situasi dan kondisi yang lebih baik

Dari situ dapat dilihat bahwa perubahan mode produksi masyarakat dari pola tanam polikultur menjadi pola tanam monokultur dengan jenis tanaman kelapa sawit lebih didorong oleh kepercayaan masyarakat bahwa akan terjadi perubahan taraf hidup yang lebih baik jika mengikuti pola tanam monokultur, masyarakat juga disadarkan bahwa lahan atau tanah yang mereka miliki sangat luas apabila tidak dikelola dengan produktif maka tanah mereka tidak bernilai oleh karena itu masyarakat berpikir dengan melihat desa lainnya terutama masyarakat transmigrasi atau masyarakat yang sudah mengikuti program plasma ini jauh mengalami peningkatan pendapatan setelah mengikuti kemitraan plasma.

Cultural Materialisme Marvin Harris menjelaskan bahwa perubahan sosial adalah mekanisme masyarakat dalam mempertahankan kelangsung hidup. Fakta menunjukkan bahwa masyarakat beradaptasi terhadap lingkungan melalui cara memproduksi makanan dan mengatur populasi agar keseimbangan makanan dan populasi terjaga. Sehingga kesediaan masyarakat petani Suku Pekal untuk mengubah mode produksi dari pola tanam polikultur menjadi pola tanam monokultur dapat dimaknai sebagai pilihan logis dalam rangka mempertahankan kelangsungan hidup. 
Keinginan masyarakat petani untuk memperbaiki taraf hidup bersambut dengan keinginan perusahaan mendapat keuntungan dari produksi kelapa sawit menyebabkan program plasma yang ditawarkan perusahaan diterima oleh masyarakat. Dimana petani berorientasi pada kesejahteraan hidup, sementara perusahaan berorientasi pada pasar dan keuntungan.

Akibatnya, jika sebelum bergabung dalam plasma masyarakat memiliki kekuasan secara penuh terhadap tanah, dengan bergabung menjadi plasma perkebunan hak milik dan kontrol atas kepemilikan dan pengelolaan mengalami pergeseran kepada perusahaan perkebunan.

Masyarakat tidak memperhitungkan apa yang akan terjadi ketika mengubah pola tanam dengan mengikuti program plasma. Kesediaan petani mengikuti program plasma yang ditawarkan menyebabkan petani harus mengikuti beberapa persyaratan yang dibuat oleh perusahaan. Petani terikat dengan waktu dan ruang serta struktur yang ada di perkebunan. Petani menempatkan dirinya sebagai pihak yang patuh pada kesepakatan awal ketika memutuskan bermitra dengan perusahaan dengan mengikuti program Plasma, meski realitanya banyak terjadi kecurangan-kecurangan di lapangan yang terjadi. Namun sebagai sebuah "keterlanjuran" petani sudah terikat dengan aturan-aturan yang ada.

Pada proses perubahan mode produksi seperti ini, posisi petani berada di bawah kendali perusahaan. Petani terikat oleh kebijakan-kebijakan perusahaan seperti penjualan buah, persentase potongan dan persentase bunga. Sehingga menyebabkan petani dalam kontrol aset produksi, yaitu: lemahnya kontrol terhadap kualitas dan pemasaran, lemahnya pada kontrol kredit atau hutang dengan plasma, lemahnya kontrol terhadap tanahnya sendiri karena sebagai agunan kredit, Lemahnya kontrol hasil panen yang ditentukan oleh perusahaan, sehingga mereka harus menjadi buruh di tanahnya sendiri. Hal ini menyebabkan petani mengalami beberapa kerugian.

Dari hasil penelitian terlihat bahwa proses produksi dengan program plasma, lebih menguntungkan perusahaan dibanding petani, dengan perbedaan sebagai berikut :

1) Keuntungan Perusahaan :

a. Tidak perlu mengeluarkan biaya investasi yang besar melalui legitimasi pemerintah perusahaan dengan mudah mendapatkan izin HGU.

b. Dana perkebunan hasil dari akumulasi surat-surat tanah dari masyarakat.

c. Perusahaan terhindar dari resiko pinjaman bank, karena dibebankan oleh petani.

d. Perusahaan terhindar dari kegagalan panen dan masalah hama karena memiliki kebun inti dan diuntungkan dengan kebun plasma sebagai tambahan komoditi produksi.

e. Perusahaan tidak memiliki resiko atas kehilangan tanah petani. 
f. Perusahaan tidak memiliki resiko atas kerusakan dan degradasi lingkungan tanah, air dan udara.

2) Kerugian Petani :

a. Tanah kebun dan rumah yang digadaikan menjadi hutang, apabila tidak dibayar maka petani akan kehilangan tanahnya.

b. Petani yang dibebankan resiko bunga bank.

c. Petani yang dibebankan resiko kegagalan panen dan hama.

d. Petani yang beresiko atas kerusakan lingkungan dan degradasi tanah.

e. Petani yang beresiko mengalami dampak sosial atas perubahan orientasi hidup sejak berubah pola perilaku hidup yang konsumtif, kehilangan tanah untuk membeli barangbarang yang sebenarnya belum menjadi kebutuhan.

f. Petani yang beresiko bergesernya nilai-nilai kebersamaan dan modal sosial karena semakin individual sejak mengerti arti penting nilai uang.

g. Perusahaan tidak melakukan pembinaan inovatif atas buah dan pelepah atau semua bagian kelapa sawit untuk bernilai ekonomi, karena petani hanya dibutuhkan tenaga dan lahannya untuk mempersiapkan bahan baku produksi perusahaan.

Dalam penelitian ini juga terungkap bahwa petani tidak mengetahui berapa persisnya jumlah pinjaman petani dengan perusahaan, hal ini disebabkan perusahaan tidak transparan dan tidak mensosialisasikan besar pinjaman petani. Dan pinjaman tersebut menjadi alat perusahaan untuk mengontrol petani dan untuk mengontrol produksi demi menjaga keuntungan.

Selama ini pada awalnya mereka tidak tahu bagaimana cara atau proses bisa terjadi hutang dan mereka tidak tahu kalau setelah kebun ditanam kelapa sawit 3 tahun masa pertumbuhan harus memenuhi kebutuhan makan keluarga sedangkan lahan sudah ditanam kelapa sawit semua, masyarakat juga tidak tahu setelah 25 tahun nanti akan seperti apa, apakah menanam kelapa sawit lagi atau tidak, ada yang berpikir untuk tetap menanam kelapa sawit jika harganya memang terus meningkat. Realitas ini karena masyarakat tidak tahu secara mendalam seperti apa jenis tanaman kelapa sawit, mereka tahu tentang budi daya setelah kebun berkembang luas dan lebih banyak belajar dari pengalaman. Ini disebabkan karena mereka tidak diberikan atau sulit memperoleh informasi tentang kelapa sawit, informasi lebih banyak dari berbagi pengalaman mulut ke mulut sesama warga petani, singkatnya mereka hanya dijadikan obyek dari pengembangan usaha perusahaan meski diposisikan menjadi mitra perusahaan, tapi perusahaan banyak melakukan intrik yang sengaja membuat masyarakat menjadi terasing dengan pekerjaanya sendiri. Tanpa disadari ini akan memperlemah posisi mereka terhadap asset produksi. 
Pinjaman petani, baik untuk modal awal maupun pinjaman berupa fasilitas menyebabkan petani kehilangan hak kepemilikan mereka atas lahan mereka sendiri. Sertifikat tanah sebagai bukti kepemilikan tanah menjadi milik bank selama pinjaman tidak diselesaikan. Konsekuensi dari pinjaman ini adalah di mana petani suatu saat berpotensi kehilangan tanahnya karena disita oleh bank (namun saat ini belum terjadi). Petani mengalami powerless terhadap asset produksi. Hal ini dikarenakan lahan petani yang diikutkan dalam pola kemitraan plasma di bawah kekuasaan bank, artinya ketika petani tidak melunasi cicilan hutang maka petani tidak berhak secara penuh atas lahan yang dimilikinya, baik atas kepemilikan maupun pengelolaannya, akan tetapi menjadi milik bank.

Modal untuk produksi bagi petani suatu hal yang sangat penting. Pada kenyataan petani akan mengalami kesulitan untuk mengakses modal tersebut kesulitan dalam mengakses dan kontrol terhadap alat produksinya. Asset produksi utama petani adalah tanah. Tanah itu sekarang tidak lagi di bawah penguasa pemiliknya, meski letaknya masih di sekitar mereka. Petani tidak lagi leluasa mengusahakan atau menanam jenis tanaman sekehendaknya, berarti kekuasaan terhadap tanah telah sirna untuk kurun waktu tertentu selaras usia tanaman di atasnya yang telah didikte oleh perusahaan perkebunan. Pada akhirnya petani menjadi buruh di lahannya sendiri, terpaksa bekerja karena hutang yang dimiliki baik kepada bank maupun kepada perusahaan.

Pada proses pembayaran hasil panen, perusahaan biasanya tidak bisa langsung membayar hasil panen dari petani akan tetapi pembayaran diakumulasi pada bulan berikutnya. Sikap perusahaan ini memaksa petani untuk mencari alternatif penjualan hasil panen bisa langsung diterima hasil penjualannya. Sementara kebutuhan petani kian meningkat dengan adanya pertumbuhan akses konsumsi keluarga dan meningginya kebutuhan hidup. Dalam penelitian ini juga terungkap bahwa hal ini menumbuhkan Toke yang memberikan kebutuhan petani. Toke memberikan pinjaman kepada petani yang membutuhkan,

Hutang adalah salah satu siasat mereka untuk tetap bertahan hidup dengan cara meminjam dengan toke, sedangkan pembayaran hasil panen oleh perusahaan yang lama sedangkan masyarakat membutuhkan cepat memenuhi kebutuhan. Petani menyadari bahwa pinjaman dengan Toke menyebabkan penghasilan semakin sedikit setiap panen sebab dipakai untuk membayar hutang baik kepada perusahaan maupun kepada Toke. Akan tetapi petani tidak memiliki pilihan lain, untuk dapat memenuhi kebutuhan terpaksa petani harus melakukan pinjaman. 
Perusahaan membiarkan praktek penjualan kepada toke tetap berlangsung, hal ini dilakukan agar masyarakat akan tetap tergantung pada perusahaan dalam bentuk hutang, sebab dengan menjual kepada Toke, maka hutang ke perusahaan tidak terbayar. Praktek penjualan hasil produksi kepada Toke justru menjebak petani pada pinjaman yang baru, sehingga dalam proses produksi pola tanam monokultur, petani justru terjebak pada ketergantungan pinjaman (hutang) dengan perusahaan dan pinjaman dengan Toke.

Perkembangan teknik penjualan dengan sistem kredit, juga menggoda petani untuk memenuhi kebutuhan kehidupan dengan pembelian sistem kredit. Dalam penelitian terungkap petani banyak membeli kendaraan bermotor, alat komunikasi, kebutuhan sehari-hari dengan sistem kredit. Hal ini dilakukan karena petani berpikir bahwa pada musim panen, petani selalu akan mendapatkan hasil panen yang dapat dipakai untuk menebus cicilan pembelian dengan sistem kredit tersebut. Akibatnya mayoritas petani memiliki cicilan kredit yang harus dibayarkan dalam setiap musim panen.

Dari penelitian terungkap bahwa dengan mengikuti program plasma dengan pola tanama monokultur kelapa sawit, petani menumbuhkan budaya pinjam (hutang), pinjaman kepada perusahaan, kepada Toke dan tukang kredit. Akibatnya hasil panen yang diterima oleh petani semakin kecil dan petani semakin tergantung dengan pemberi pinjaman. Temua lapangan tersebut sangat sejalan jika dikorelasikan dengan penjelasan Dos Santos (dalam Budiman, 2000:68) dimana pada level negara perkembangan pembangunan dengan menggunakan pendekatan modernisasi justru menyebabkan tiga ketergantungan, 1) ketergantungan dominasi (kolonial) 2) ketergantungan finansial-industrial; 3) ketergantungan teknologi-industrial. Akan tetapi hubungan pada level petani dan perusahaan maka ketiga ketergantungan tersebut terjadi pada petani terhadap perusahaan.

Dominasi perusahaan terhadap petani sangat besar melalui kebijakan, akibatnya petani menjadi lemah berhadapan dengan perusahaan. Petani mengalami ketergantungan modal, perusahaan memberikan pinjaman kepada petani dan terakhir petani mengalami ketergantungan teknologi, petani tidak mengetahui seluk beluk produksi kelapa sawit, petani hanya diberikan pengetahuan bagaimana membersihkan kebun dan bagaimana cara memanen.

Perubahan pola tanam masyarakat petani dari polikultur menjadi monokultur dengan sistem plasma dalam perkembangan proses produksi justru menyebabkan petani terjebak pada hutang yang harus dibayar setiap musim panen. Pendapatan petani harus dikurangi dengan pembayaran kepada perusahaan, pembayaran kepada Toke dan pembayaran angsuran/kredit/cicilan yang diikuti petani. 


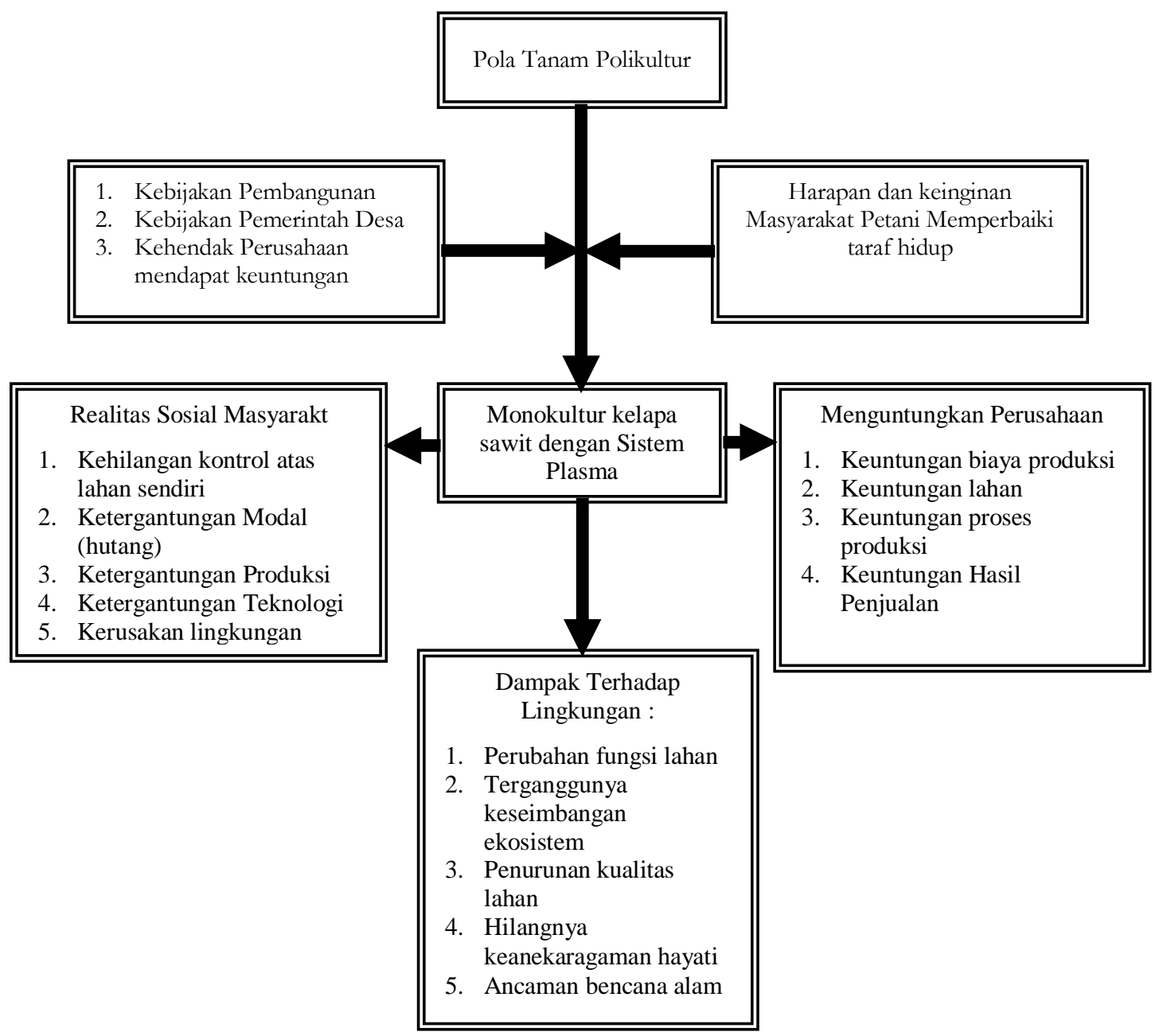

Bagan 2. Perubahan Mode Produksi

Dalam paradigma Cultural Materialisme Marvin Harris telah dinyatakan bahwa perubahan mode produksi masyarakat akan mendorong perubahan pada struktur sosial, walaupun Cultural Materialisme Marvin Harris juga meyakini bahwa struktur sosial dapat mendorong perubahan pada mode produksi (infrastruktur). Kebijakan pembangunan yang tujuan awalnya untuk mensejahterakan masyarakat tetapi dengan mekanisme yang terjadi pada petani dengan model kemitraan yang tidak transparan justru merugikan, dimana realitanya justru menyebabkan petani terjebak dengan toke dan perusahaan, petani mengalami ketergantungan modal, produksi dan teknologi. Perubahan mode produksi cenderung berakibat negatif terhadap masyarakat petani, hal ini sejalan dengan prediksi teoritik dimana struktur sosial yang berkembang juga akan merugikan masyarakat petani.

Dalam penelitian terungkap kerugian-kerugian yang dialami petani ketika mengikuti perubahan mode produksi dari pola tanam polikultur menjadi pola tanaman monokultur dengan sistem plasma sehingga perubahan mode produksi sesungguhnya tidak mensejahterakan petani. Padahal indikator pembangunan dalam sebuah negara dianggap berhasil ketika tingkat 
produktivitas ekonomi, keadilan sosial, pemerataan kesejahteraan, meningkatnya kualitas hidup dan indikator kelestarian lingkungan yang terlindungi dari dampak negatif pembangunan.

\section{Perubahan Mode Reproduksi}

Jumlah penduduk dalam satu wilayah akan berpengaruh pada lahan pemukiman, lahan produksi, kebutuhan konsumsi (pangan), jumlah tenaga kerja, dan lainnya. Artinya perubahan komposisi kependudukan akan berpengaruh pada sistim sosial dalam masyarakat. Hal ini yang menyebabkan dalam paradigma Cultural Materialisme Marvin Harris, mode reproduksi diletakan pada infrastruktur masyarakat yang merupakan basis dalan perubahan sosial. Karena berkaitan erat dengan keberlangsungan sistem sosial, maka masyarakat akan selalu mengontrol dan memperhitungkan komposisi kependudukan.

Dalam skema perubahan sosial Marvin Harris, dijelaskan bahwa perubahan mode reproduksi akan mendorong perubahan pada struktur sosial. Perubahan mode reproduksi berkaitan dengan perubahan komposisi penduduk baik diakibatkan oleh pertambahan penduduk atau pengurangan penduduk ataupun program-program yang berkenaan dengan kependudukan.

Jumlah penduduk masyarakat petani yang sedikit dan tidak berimbang dengan luas lahan (pemukiman dan hutan adat) serta keterbatasan pengetahuan dan keahlian dalam mengelolanya yang disebabkan karena dahulu masyarakat belum mampu mengakses fasilitas dasar seperti pendidikan.

Sebelum masuknya program transmigrasi, masyarakat mengalami keterisolasian interaksi dan kebudayaan dan hidup eksklusif di tanah mereka sendiri. Akibatnya masyarakat tidak mengalami pertumbuhan ekonomi yang signifikan karena pengolahan sumber daya alam dan pola produksi pertanian hanya untuk memenuhi kebutuhan sehari-hari keluarga petani.

Masuknya program transmigrasi menyebabkan perubahan pada masyarakat desa di bengkulu utara, baik perubahan dari sisi material/fisik seperti penduduk semakin ramai, pemukiman warga bertambah, jalan-jalan desa mulai dibangun, dibukanya lahan-lahan hutan menjadi lahan pemukiman dan lahan perkebunan terjadi juga perubahan pada sisi sosial seperti interaksi dengan kebudayaan lain, perkembangan pengetahuan. Masyarakat komunitas Suku Pekal menjadi lebih terbuka dalam berinteraksi dan masyarakat Suku Pekal lebih terbuka menyerap kebudayaan lain. 


\section{SIMPULAN}

Perubahan infrastruktur (mode produksi dan mode reproduksi) yang terjadi karena adanya perubahan sistem pertanian pada masyarakat petani telah menyebabkan masyarakat petani memiliki ketergantungan pada pihak luar (perusahaan perkebunan, bank, lembaga kredit, toke). Ketergantungan tersebut terjadi karena bergesernya kontrol dan penguasaan petani pada asetaset produksi yang selama ini dikuasainya. Pergeseran tersebut terjadi karena berubahnya sistem pertanian, sistem produksi dan teknologi, aktivitas kerja, dan fungsi lahan.

\section{DAFTAR PUSTAKA}

Denzin, Norman K \& Lincoln, Yvionna S. 2009. Handbook Of Qualitative Research. Terj. Dariyatno, et. al. Yogyakarta : Pustaka Pelajar.

Elfitra. 2009. Ekonomi Kebun Sawit dan Perubahan Sosial Masyarakat Desa. Bandung : Unpad Press.

Fakih. Mansour. 2008. Runtubnya Teori Pembangunan dan Globalisasi. Yogyakarta : Insistpress .2010. Bebas Dari Neoliberalisme. Yogyakarta : Insistspress

Fatah, Lauthfi. 2006. Dinamika Pembangunan Pertanian dan Pedesaan. Banjarbaru Kalimantan Selatan : Jurusan Sosek Fakultas Pertanian Universitas Lambung Mangkurat dengan Pustaka Buana.

Fukuyama, Francis. 2002. The Great Disruption. Qalam : Yogyakarta.

FWI/GFW. 2001. Keadaan Hutan Indonesia. Bogor, Indonesia: Forest Watch Indonesia dan Washington D.C.: Global Forest Watch.

Garna, Judistira K. 1993. Teori-Teori Perubahan Sosial. Bandung : Program Pascasarjana UNAD.

Harris, Marvin. 1979. Cultural Materialism; The Struggle for A Science of Culture. Ney Work: Random House.

Horton, Paul B \& Hunt, Chester L. 1991. Sosiologi Jilid I. Terj. Aminuddin Ram \& Tita Sobari. Jakarta : Erlangga

Lauer, Robert H. 1993. Perspektif Tentang Perubahan Sosial. Terj. Alimandan. Jakarta : Rineka Cipta.

N. H. T. Siahaan. 2004. Hukum Lingkungan dan Ekologi Pembangunan. Jakarta : Erlangga.

Pardamean, maruli. 2008. Panduan Lengkap Pengelolaan Kebun dan pabrik Kelapa Sawit. Jakarta : Agroedia Pustaka.

Risza, Suyatno. 2010. Masa Depan Perkebunan Kelapa Sawit Indonesia. Yogyakarta : Kanisius

Ranjabar, Jacobus. 2008. Perubahan Sosial Dalam Teori Makro ; Pendekatan Realitas Sosial. Bandung. Alvabeta CV.

Siahaan, N.H.T. 2004. Hukum Lingkungan dan Ekologi Pembangunan. Jakarta : Erlangga.

Susilo, Dwi Rachmad K. 2008. Sosiologi Lingkungan. Jakarta : Raja Grafindo Persada.

Soekanto, Soerjono. 1984. Beberapa Teori Sosiologi Tentang Struktur Masyarakat. Jakarta : CV.

Rajawali.

Soelaiman, M. Munandar. 1998. Dinamika Masyarakat Transisi. Yogyakarta : Pustaka Pelajar. 
Sztompka. Piotr. 2002. Sosiologi Perubahan Sosial. Terj. Alimandan. Jakarta. Prenada.

Yusriyadi. 2010. Industrialisasi dan Perubahan Fungsi Sosial Hak Milik Atas Tanah. Yogyakarta : Genta Publishing

Colchester, Marcus. et.al. 2006. Tanah Yang Dijanjikan; Minyak Sawit dan Pembebasan Tanah di Indonesia; Implikasi terhadap Masyarakat Lokal dan Masyarakat Adat. Bogor: Sawit Watch

Herman, et.al. 2009. Analisis finansial dan Keuntungan yang Hilang dari Pengurangan Emisi Karbon Dioksida pada Perkebunan Kelapa Sawit. Bogor : Jurnal Litbang Pertanian, 28(4).

Huzairin, Achmad. 2002. Perubahan Struktur Kepemilikan dan Fungsi Tanah (Studi Kasus : Masyarakat Cobogo Kecamatam Cisauk. Tanggerang). Jakarta : Program Pascasarjana Manajemen Pembangunan Sosial Jurusan Sosiologi Fakultas Ilmu Sosial dan Ilmu Politik Universitas Indonesia.

Manurung, E. G. Togu. 2001. Analisis V aluasi Ekonomi Investasi Perkebunan Kelapa Sawit di Indonesia. Environmental Policy and Institutional Strengthening IQC OUT-PCE-I-806-9600002-00. Jakarta : Indonesia.

Marti, Serge. 2008. Hilangnya Tanah Berpijak; Dampak Ekspansi Perkebunan Kelapa Sawit Terhadap Hak Asasi Manusia di Indonesia. Bogor : Sawit Wacth.

Syahaza, Almasdi. 2005. Development Impact of Palm Oil Plantation Toward Rural Economic Multiplier Effect in Riau Province. Lembaga Penelitian Universitas Riau : Pekanbaru. Telah dipublikasikan dalam Jurnal Ekonomi, Th.X/03/November/2005. Jakarta : PPD\&I Fakultas Ekonomi Universitas Tarumanagara.

Yayasan Ekosistem Lestari (YEL) dan Paneco. 2008. Bagaimana Perkebunan Kelapa Sawit di Tripa Beresiko Mendatangkan Bencana, Berkontribusi terbadap Pemanasan Global dan Membuat Populasi Unik Orangutan Sumatera Menjadi Punab: Hutan Rawa Gambut Tripa, Aceh, Sumatera, Indonesia. Indonesia : PaNeco Foundation for Sustainable Development and Intercultural Exchange.

Seputar Info Bengkulu. 2010. Bengkulu Lahan Empuk Investasi 2010 (PerkebunanSawit).Melalui:<http://infobengkulu.blogspot.com/2010/07.html> [03/8/11].

Yondri, et.al. 2004. Identifikasi Budaya Suku Bangsa Pekal Kabupaten Bengkulu Utara. Padang: Balai Kajian Sejarah dan Nilai Tradisional Padang. Melalui: $<$ http://www.bpsntpadang.info $>$ [03/5/11]. 